\title{
Digital Intellectual Capital of Russian Companies and its Impact on Financial and Innovation Performance
}

\author{
Ilia Chernenko*, Natalya Kelchevskaya, and Irina Pelymskaya \\ Ural Federal University, 620002 Ekaterinburg, Russia
}

\begin{abstract}
The paper aims to investigate the level of accumulated digital intellectual capital and investments in digital transformation in the Russian regions and study its impact on the gross regional product and companies' revenue, as well as on the innovative activity of companies. The study relies on the multiple regression method to find significant relationships between digitalization and performance indicators in 85 Russian regions and cities of federal significance. The originality of the approach used in this study lies in the development of the digital capital theory: the authors assess the impact of accumulated digital intellectual capital and investment on the performance of manufacturing and service companies and show the difference in return on investment between sectors. The results of the study show that though Russian regions are at the initial stage of the digital economy development, digitalization has a significant positive impact on the financial and innovative performance. Manufacturing companies primarily use structural capital to create customer value. Service-oriented companies also receive a positive return on investment in human and relational capital. The results obtained can be applied in practice by the business community to support investment decisions and analyse the processes of creating digital intellectual capital in companies.
\end{abstract}

\section{Introduction}

Over the past two decades, there have been two revolutions, which, on the one hand, led to the emergence of an intangible economy, where the main value is created from intellectual capital, and on the other hand, they marked the development of the digital economy, an increase in the level of information technologies and cyber-physical systems implementation referred to as Industry 4.0 [1]. Intellectual capital in digital economy is considered as a strategic resource of organizations which offers opportunities and brings challenges regarding to performance management and control. The peculiarity of the current stage of global economy development is that the added value in organizations has not only monetary characteristics, but is also reflected in the network nature of companies, network interaction, increased importance of the qualitative characteristics of intellectual resources [2]. Consequently, digital technologies provide a platform and tools for

\footnotetext{
* Corresponding author: i.m.chernenko@urfu.ru
} 
cooperation between business, the public sector and government, focusing on the creation of intangible assets associated with the codification of knowledge, its exchange and implementation in the form of intellectual capital.

Many manufacturing and service companies are going through the stage of digital transformation, radical revision of the main business processes, increasing the flexibility of solutions, business transparency for stakeholders and improving reputation [3]. First, there is a rethinking of supply chains, using digital platforms that aims to support the transparency and velocity of material flows, promoting their decentralization and real time management [4], [5]. Second, digitalization improves the financial culture and financial performance of banks [6]. Third, the introduction of digital technologies determines the transformation of the production process, an increase in resource efficiency [7], as it creates the opportunity to apply alternative energy and materials and support a high level of individualization in a short time [8]. Fourth, digitalization leads to the development and transformation of business models, ways to create and retain customer value. All the benefits of advanced information technologies contribute to supporting the business model innovation in companies [9], [10].

The term digitalization is used to denote the implementation of digital technologies in society and business, which lead to a consistent transformation of key business processes in companies and improve the connectivity of business units [11]. The implementation of digital technologies has a number of positive economic effects on the various strategic activities of companies aimed at sustainable development and achieving technological advantage. The mechanisms of digitalization that impact on productivity are revealed through the cooperation of companies in supply chains. They can be tracked through a decrease in the volume of organizational routines and the amounts of time invested in processing large amounts of data [12]. Digitalization leads to dramatic changes in the workplace and forces mangers to reconsider the methods of solving everyday problems, since it affects the organization of material flows and the processes of creating products, both at the design stage and at all consequent stages of manufacturing [13], for example, it can be implemented in form of additive technologies [14]. The work of companies on the basis of network principles opens up new opportunities for increasing resource efficiency and maintaining the principles of a modern economy, for example, when organizing circular flows of resources [7].

At the national level, digitalization is becoming an instrument to implement a sustainable development strategy. The countries of the European Union focus on improving consumer access to goods and services through the broadband Internet connection [15]. Some of them deepen digital economic policy, for example, Germany, since 2011 have been developing the concept of government support for digital production based on the Industry 4.0 concept [16], [ 17]. Emerging economies are also generally undergoing a digital transformation that is changing conventional opinion on business and social interactions. Despite the fact that the Russian regions retain traditional industrial values, there is a gradual awareness of the need to support network entrepreneurship, reform infrastructure, and support the development of artificial intelligence technologies [15]. Russian economic regulators aim to inspire business digitalization and support those industries that are focused on maintaining export competitiveness in the Int. arena [18]. In 2017, the Russian government adopted a program for the digital economy development until 2024, which emphasizes the strategic importance of information technologies as they support innovations in business and society [19]. Despite this, Russia remains a country with a developing digital economy: certain areas of administrative regulation and business unevenly introduce information technologies, which leads to infrastructural heterogeneity [20]. 
The considered positive effects of digitalization at the local and national levels in most cases signal that there are a number of intangible resources, such as software, cyberphysical systems and technologies for mining big data, cloud technologies and machine learning, which create added customer value, and, hence, can be attributed to intellectual capital. These trends indicate that there is a critical call for research that reveals the role of intellectual resources in maintaining the performance of manufacturing and service companies and regions in general. The purpose of this article is to study the impact of digital intellectual capital on the financial performance of companies and their innovative activity in 85 Russian regions. The main hypothesis of the study is the assumption that there is a significant positive relationship between digital intellectual resources and the performance of companies in industrial and service sectors. To determine the financial performance, the study uses the indicators of the gross regional product (GRP) and revenue per company. The innovative activity of companies is expressed through the indicator of produced innovative products and services that have been supplied to local and Int. markets. Digitization is measured through adoption rates of technological solutions such as broadband Internet, ERP systems, RFID technologies, cloud technologies and software investments. In the paper, the authors also compared the return on investments in digital intellectual capital with the return on the development of other types of companies' intangible resources such as physical capital. The article is structured as follows. First, we review the literature and develop the theory of digital capital and put forward hypotheses. Then we analyse the level of accumulated digital intellectual capital in Russian regions and make a conclusion about its impact on financial performance and innovation activity. In conclusion, we reveal the practical significance, limitations and directions for further research.

\section{Digital Technologies as a Component of Intellectual Capital: Theoretical Background}

A significant problem in studying the contribution of digitalization and information technology to productivity is the limited understanding of the specific mechanisms of their impact on overall performance, both at the level of companies and national economies [21]. The main assumption for the analysis used in this study is the presence of a special stock of intellectual capital that digitalization provides in companies. Digital intellectual capital is an additional stream of added customer value that increases the competitiveness of companies through the adaptation of broadband Internet, advanced digitalization, the development of ERP systems, radio frequency identifiers (RFID), cloud technologies and software acquisition [1].

The current literature covers various approaches to reflecting the impact of digitalization and information technology on the processes of creating and using intangible resources. The classic work of Brynjolfsson and Yang (1996) suggests the existence of computer capital, which refers to the physical hardware, software, and technical support of companies' digital infrastructure [21]. Liu (2008) proposes the concept of digital capital, which is acquired through knowledge and relationships supported by the adoption of the Internet, and notes its positive impact on the financial sector development [22]. By using the internet, people gain access to their financial resources and personalised analytics to make quick and flexible investment or consumption decisions, which undoubtedly creates high customer value. Molodchik, Paklina and Parshakov (2018) believe that relationships emerging in the digital space constitute specific relational capital [23]. Authors argue that cross-fertilization of the big data and intellectual capital concepts can provide valuable insights by developing theory and so-called digital dividends for practice. In this study, 
three components of digital intellectual capital are developed that correspond to the traditional ideas about its nature: structural, relational, human capital [24], [25].

Digital structural capital. The essential component of digital intellectual capital that is most transparent for economic analysis and suitable for disclosure in financial statements is reflected in codified knowledge. Program codes, formalized approaches to information processing, resource management systems (ERP), instructions and information know-how form the basis of the company's digital environment [26]. Some structural components of digital intellectual capital can be reflected in financial statements as intangible assets, for example, investments in software and the results of research and development [27]. For industrial companies, intelligent solutions that support high-tech production, such as 3D printing, additive technologies in a broad sense, also play a significant role [28]. Structural capital can also include research and development expenditures aimed at creating significantly improved or innovative goods and services [29]. The considered components of structural capital provide value creation by increasing transparency and speed of work by reducing the labor intensity of information processing, automatic reporting, etc.

Digital relational capital. Relations with stakeholders (customers, business partners, employees and local environment), business reputation and company image together provide the emergence of relational capital [30]. The rapid growth of e-commerce has significantly influenced the level of customer satisfaction through unprecedented individualization of product and service offerings, an increase in the number of alternatives, and the speed of production and delivery of goods [31]. One of the common indicators of relational capital is the cost of marketing and promoting products and services, as well as the fact of participation in joint projects with key partners in the form of strategic alliances [32].

Digital human capital. The development of the digital environment in companies requires new competencies and knowledge from employees, the support of which is becoming one of the main challenges of digital transformation [3]. Human capital provides a dynamic transformation of structural capital, increasing its relevance for business situations, since codified knowledge itself is limited due to the variability of the environment in which the company operates [33]. On the one hand, digitalization leads to job cuts in a number of industries that are associated with routine information processing operations or monotonous production processes [11]. On the other hand, digitalization increases the attractiveness of jobs by increasing the level of creativity, innovativeness of work and, in general, has a positive effect on motivation [12], improves the ergonomics and safety of processes [11].

Impact of intellectual capital on performance. A significant stream of the research in the recent literature is aimed at finding the relationship between the performance of companies and the use of intellectual capital. One of the main tasks is the measurement of intellectual capital [34]. The first large group of studies is based on a rigorous approach according to which intellectual capital can be measured by quantitative financial indicators [35] - [37]. These studies generally demonstrate that intellectual input contributes to higher returns on assets and investments, and the formation of income streams. The second group of studies relies on various quantitative indicators, including empirical materials collected by sociological methods [38], [39], a significant role is assigned to qualitative indicators that are used in the disclosure of intangible assets in reporting [40]. We believe that for performance analysis it is necessary to use financial and non-financial indicators: the level of implementation of digital technologies in companies and the level of investments in digital intellectual capital. Investments in intellectual capital, including in digitalization technologies, can also be considered as a source of increasing innovative performance, both at the individual and national levels. Among the important indicators of performance, one 
can single out the intensity of implementation and development of innovations in companies [41], [42].

Consequently, the additional flows of intellectual capital that digitalization brings with it have a positive effect on the capabilities of companies, as well as their ability to achieve their goals, that is, financial and innovative performance. Financial performance can be measured as the company's ability to generate a steady income stream in a strategic perspective [32]. Digital intellectual capital improves the connectedness of the business environment and consumers, and therefore leads to the emergence of additional customers, driving revenue growth for companies. In addition, the ability to increase product customization, shorten production cycle and flexibility in logistics solutions, also shift demand from other market segments and generate additional revenue streams. Thus, we put forward the first hypothesis of the study:

Hypothesis 1. There is a significant positive relationship between the level of digital intellectual capital and the financial performance of companies, expressed in the ability to generate a steady income stream in the current period.

Digital intellectual capital in manufacturing and service companies. One of the important tasks of this study is to study the differences in the return on investment in the components of conventional and specific digital intellectual capital in the manufacturing and service sectors. Studies show that for manufacturing companies the processes of creating and using structural capital play a key role, while human and relational ones are intensively used to create customer value in service-oriented companies [43]. Manufacturing companies focus on sustainable, transparent and measurable forms of intellectual capital. Service companies are more focused on cooperation with customers and the use of expertise, complex knowledge of employees, which are supported by dynamic processes of knowledge exchange [44]. Thus, we put forward the second hypothesis of the study:

Hypothesis 2. There is a significant positive relationship between investments in digital intellectual capital and the sales revenue from innovative products and services. Wherein structural capital components play a significant role for manufacturing companies, and human and relational capital are crucial for service-oriented companies.

\section{Methods and Data}

The multiple linear regression method was applied to test the proposed hypotheses. In the sample used for the study, the region is the unit of observation. A total sample of 85 regions is studied, two federal cities (Moscow, St. Petersburg) are considered. Models are tested for 2017 and 2018 separate data sets.

Financial performance indicators of companies and regions, as well as indicators of innovation activity are used as dependent variables. The financial performance of companies is measured as the ability to generate an income stream, that is, the average revenue per company in the region in roubles $\left(L N \_S A L\right)$. In addition, for each region, the impact of digital intellectual capital on the integral performance indicator - the logarithm of the gross regional product in roubles $\left(L N_{-} G R P\right)$ - is assessed. The volume of sales of innovative goods and services in roubles is the dependent variable in the third type models (INN_IND for manufacturing companies, INN_SER for service companies, INN_ALL for all companies). These indicators reflect the relationship between investments in the physical and intellectual, including digital, capitals and the innovative performance of companies in the regions.

Two groups of indicators are used as independent variables - indicators of the level of adaptation of digital technologies in the region, as a percentage of the total number of organizations, as well as investments in elements of intellectual capital, including structural 
capital (software), which is used to maintain innovative activity. The indicators of the implementation of cloud services and technologies ( $d_{-}$Cloud_SC), radio frequency identifiers (d_RFID_SC) and resource management systems $\left(d_{-} R F I D \_S C\right)$ are classified as components of digital intellectual capital. The considered components support the formation, storage and use of codified knowledge, they support obtaining value from the use of formalized intangible assets, such as software and information technology in general. The indicators of broadband Internet adoption in companies (d_Internet_RC) and the presence in companies of systems that support electronic sales (d_el_sale_RC) are classified as indicators of digital relationship capital, since they allow to support communication and information exchange between stakeholders.

Investments in structural capital (the second group of independent variables) are measured on the basis of the following indicators: research and development costs in roubles $\left(S C_{-} R N D\right)$, design costs, product enhancement $\left(S C \_D E S I G\right)$, costs of acquiring new technological solutions, instructions and know-how $(\overline{S C}+T E C H)$, including patents $\left(S C_{-} P A T\right)$, costs of engineering, design and pre-project preparation of innovations $\left(S C_{-} I N G I\right)$ Investment in digital structured capital was defined as the cost of software to support innovation (SC_SOFT) Investments of companies in employee training (HC_EDU) in the third type models are considered as investments in human capital.

In studying the impact of digital intellectual capital on financial and innovative performance, the following models are proposed:

$L N_{\text {_GRP }}=b_{0}+b_{\mathrm{n}} \times($ Digital intellectual capital $)+b_{\mathrm{m}} \times($ Sales of innovation goods and
services $)+b_{\mathrm{f}} \times($ Investments in software $)+b_{\mathrm{c}} \times($ Control variables $)+\varepsilon$

$L N \_S A L=b_{0}+b_{\mathrm{n}} \times($ Digital intellectual capital $)+b_{\mathrm{m}} \times($ Sales of innovation goods and services $)+b_{\mathrm{f}} \times($ Investments in software $)+b_{\mathrm{c}} \times($ Control variables $)+\varepsilon$

$L N \_I N N=b_{0}+b_{\mathrm{n}} \times($ Ln Investments in intellectual capital $)+\mathrm{b}_{f} \times($ Ln Investments in software, digital structural capital $)+b_{\mathrm{c}} \times($ Control variables $)+\varepsilon$

The indicators of sales of innovative goods and services in the corresponding periods are used as control variables in the first and second models. It is assumed that the level of innovative activity directly affects the indicators of the financial performance of companies in the considered regions. In the third model, indicators of investment in physical capital (machinery and equipment) are used as control variables, which are reflected in the level of innovative performance. To test the third model, companies that introduced product or process innovations in 2017 and 2018 are selected.

The study uses three data sources. Data on financial performance for regions were obtained from the Rosstat information base [45]. Data on investment activity and investments in various types of intellectual capital among innovatively active companies in the regions of Russia were obtained from sources [46], [47]. Data on the level of adaptation of digital technologies, which reflect the level of accumulated digital intellectual capital, were obtained from the source [48].

\section{Results and Discussion}

The overall level of accumulated digital intellectual capital in Russian regions remains very moderate (Table 1). A significant proportion of companies use broadband Internet services to create digital relational capital. Compared to companies in developed countries, Russian companies are doing well in the field of advanced digitalization, actively using cloud technologies and services. The average value of cloud services adoption rate for Russian regions was $24.6 \%$ in 2018 . For comparison, we cite data on the introduction of digital 
technologies in developed European countries in 2018. Greece, for example, is in a cluster comparable to Russia in terms of digitalization. The example of Denmark is also considered, as the country is one of the leaders in digitalization in the European Union, because more than half of all companies in this country use cloud services, broadband Internet is implemented in almost all organizations.

Table 1. Descriptive statistics for variables in models to test the first hypothesis and Int. comparisons of digitalization indicators.

\begin{tabular}{|l|r|r|r|r|r|r|}
\hline \multirow{2}{*}{ Variables } & \multicolumn{2}{|c|}{ Russia, 2017} & \multicolumn{2}{c|}{ Russia, 2018} & \multicolumn{1}{c|}{$\begin{array}{c}\text { Denmark, } \\
2018\end{array}$} & $\begin{array}{c}\text { Greece, } \\
2018\end{array}$ \\
\cline { 2 - 7 } & \multicolumn{1}{|c|}{ Mean } & \multicolumn{1}{c|}{ S.D. } & \multicolumn{1}{c|}{ Mean } & \multicolumn{1}{c|}{ S.D. } & \multicolumn{2}{c|}{ Comparisons } \\
\hline LN_GRP & 26,85 & 1,14 & 26,95 & 1,16 & -- & \multicolumn{1}{c|}{--} \\
\hline LN_SAL & 16,68 & 0,85 & 16,85 & 0,87 & --- & -- \\
\hline d_Internet & 83,0 & 7,2 & 85,5 & 5,7 & 100 & 85 \\
\hline d_Cloud & 21,9 & 4,9 & 24,6 & 4,6 & 56 & 13 \\
\hline d_RFID & 4,5 & 1,2 & 4,9 & 1,2 & 9 & 7 \\
\hline d_ERP & 10,5 & 3,9 & 11,8 & 3,9 & 40 & 35 \\
\hline d_el_sale & 8,9 & 3,6 & 15,3 & 7,3 & 32 & 12 \\
\hline
\end{tabular}

Note. * significant at the level $<10 \%$; ** significant at the level $<5 \%$; *** significant at the level at $<1 \%$.

The results of the regression analysis show that the level of accumulated digital capital makes a significant positive contribution to the financial performance of companies and supports the creation of an additional gross regional product (Table 2). First, investments in structural digital capital in various forms have a positive effect on the growth of revenue of companies in Russian regions and ensure the formation of an additional gross regional product. Second, there is a heterogeneity in the significant components of digital intellectual capital in the two periods considered. Digital relational capital metrics do not significantly affect the competitive advantage of companies. Third, despite the heterogeneity of digitalization in Russian regions, there is a stable role of structural digital capital in ensuring high financial performance of companies, both in the production, product-oriented and service sectors of the economy. Acquisition of software, implementation of company resource management systems are priority areas of investment in the emerging digital economy in Russia. The control variables also showed their significance in accordance with expectations: the innovative activity of companies has a positive effect on the financial performance of companies and regions in general. Thus, the first hypothesis of the study is confirmed.

Table 2. Unstandardized regression coefficients for testing the first hypothesis.

\begin{tabular}{|l|r|r|r|r|r|r|r|r|}
\hline \multirow{2}{*}{ Variables } & \multicolumn{4}{|c|}{ Model 1. Dependent: In GRP } & \multicolumn{3}{c|}{ Model 2. Dependent: In sales per company } \\
\cline { 2 - 9 } & \multicolumn{2}{|c|}{$\mathbf{2 0 1 7}$} & \multicolumn{1}{|c|}{$\mathbf{2 0 1 8}$} & \multicolumn{1}{c|}{$\mathbf{2 0 1 7}$} & \multicolumn{1}{c|}{$\mathbf{2 0 1 8}$} \\
\hline & \multicolumn{1}{|c|}{$t$} & \multicolumn{1}{c}{$t$} & \multicolumn{1}{c|}{$b$} & \multicolumn{1}{c|}{$t$} & \multicolumn{1}{c|}{$b$} & \multicolumn{1}{c|}{$t$} \\
\hline Constant & $-0,017$ & $-1,23$ & $-0,004$ & $-0,21$ & 0,002 & 0,13 & 0,002 & 0,13 \\
\hline d_Internet_RC & $0,047^{* *}$ & 2,43 & 0,020 & 0,76 & 0,003 & 0,16 & $-0,013$ & $-0,59$ \\
\hline d_Cloud_SC & 0,135 & 1,48 & 0,020 & 0,19 & 0,121 & 1,54 & $0,184 * *$ & 1,99 \\
\hline d_RFID_SC & $0,104^{* * *}$ & 3,24 & $-0,018$ & $-0,45$ & $0,089^{* * *}$ & 3,21 & $-0,009$ & $-0,260$ \\
\hline d_ERP_SC & $-0,013$ & $-0,52$ & 0,003 & 0,26 & $-0,027$ & $-1,17$ & $-0,004$ & $-0,32$ \\
\hline d_el_sale_RC & $0,048^{* * *}$ & 2,92 & $0,037^{*}$ & 1,75 & 0,004 & 0,30 & 0,008 & 0,45 \\
\hline INN_IND & $0,062^{*}$ & 2,03 & $0,068^{* *}$ & 2,38 & $-0,091 * * *$ & $-3,48$ & $-0,003$ & $-0,12$
\end{tabular}


Table 2. Continued

\begin{tabular}{|c|c|c|c|c|c|c|c|c|}
\hline SC_SOFT & 0,002 & 0,14 & $0,096 * * *$ & 3,90 & $0,068 * * *$ & 3,61 & $0,076 * * *$ & 3,62 \\
\hline $\mathrm{R}^{2}$ & \multicolumn{2}{|c|}{0,658} & \multicolumn{2}{|c|}{0,528} & \multicolumn{2}{|c|}{0,541} & \multicolumn{2}{|c|}{0,395} \\
\hline Adj. $R^{2}$ & \multicolumn{2}{|c|}{0,622} & \multicolumn{2}{|c|}{0,479} & \multicolumn{2}{|c|}{0,493} & \multicolumn{2}{|c|}{0,331} \\
\hline $\mathrm{F}$ & \multicolumn{2}{|c|}{$18,3 * * *$} & \multicolumn{2}{|c|}{$10,6^{* * *}$} & \multicolumn{2}{|c|}{$11,2 * * *$} & \multicolumn{2}{|c|}{$6,2 * * *$} \\
\hline Durbin-Watson & \multicolumn{2}{|c|}{1,755} & \multicolumn{2}{|c|}{1,723} & \multicolumn{2}{|c|}{1,845} & \multicolumn{2}{|c|}{1,868} \\
\hline $\mathrm{N}$ (regions) & \multicolumn{2}{|c|}{85} & \multicolumn{2}{|c|}{85} & \multicolumn{2}{|c|}{85} & \multicolumn{2}{|c|}{85} \\
\hline
\end{tabular}

Note. $*$ significant at the level $<10 \%$; ** significant at the level $<5 \%$; *** significant at the level at $<1 \%$.

A detailed analysis of digital intellectual capital shows that Russian regions are characterized by the heterogeneity of the introduction of conventional and advanced information technologies (Fig. 1). A significant part of investment in intellectual capital is concentrated in the European part of Russia. The central and eastern regions are only the «followers» of technological development trends, as they need additional investments to develop digital infrastructure. Thus, at the level of individual regions, the contribution of digital intellectual capital remains insignificant or moderate in terms of its impact on economic development.

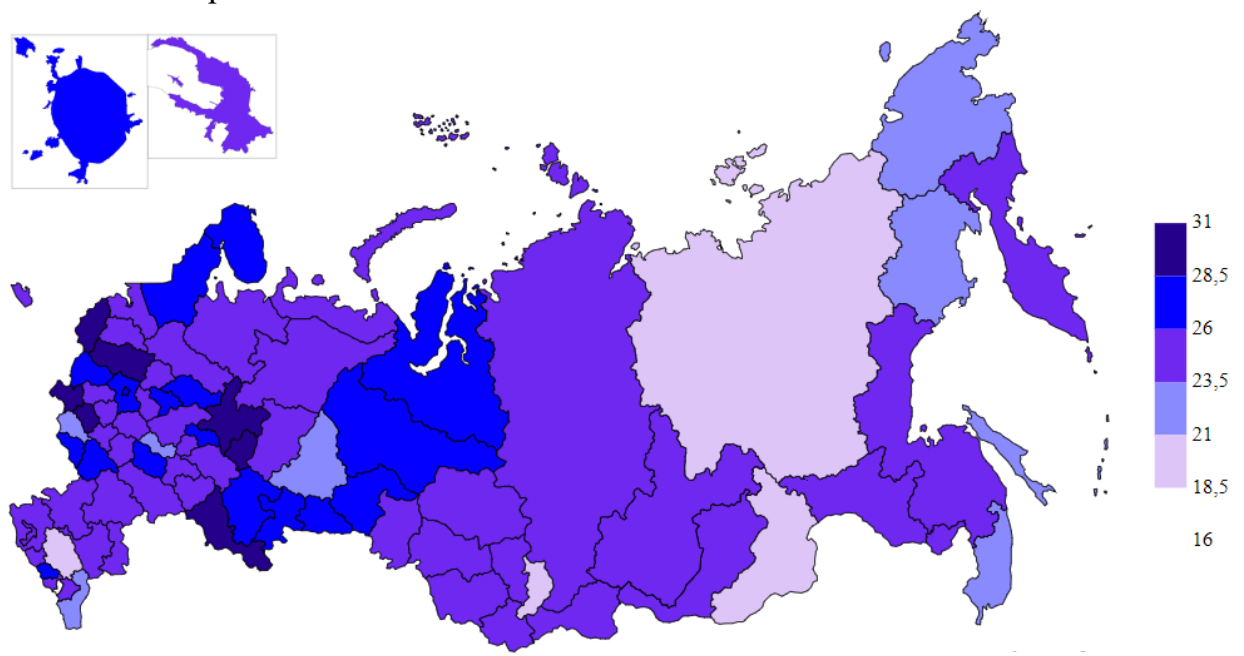

Fig. 1. Assessment of the level of accumulated digital intellectual capital in Russian regions in 2018 based on the digitalization index. Compiled by authors based on estimations in [48].

The analysis of statistical data shows that Russian companies are also actively investing in the components of intellectual capital in both periods considered (Table 3). In general, the level of investments in maintaining innovative activity does not exceed $3 \%$ of the proceeds from innovative goods and services in 2017 and 2018. The share of investments in intellectual capital (research and development, software) does not exceed $1-2 \%$ of companies' revenues, which shows a gap in the development of Russian companies and their partners from developed countries. Investment patterns are also heterogeneous, with a significant portion of physical capital assets such as innovative equipment and machinery. Russian innovative manufacturing companies invest in physical and intellectual capital relatively more than their partners from the service sector. 
Table 3. Descriptive statistics for variables in models to test the second hypothesis. Performance indicators are measured in logarithms of roubles, indicators of investment in intellectual and physical capital are measured in million roubles.

\begin{tabular}{|c|c|c|c|c|c|c|c|c|}
\hline \multirow[b]{3}{*}{ Variables } & \multicolumn{4}{|c|}{2017} & \multicolumn{4}{|c|}{2018} \\
\hline & \multicolumn{2}{|c|}{ Manufacturing } & \multicolumn{2}{|c|}{ Service } & \multicolumn{2}{|c|}{ Manufacturing } & \multicolumn{2}{|c|}{ Service } \\
\hline & Mean & S.D. & Mean & S.D. & Mean & S.D. & Mean & S.D. \\
\hline LN_INN_IND & 20,87 & 6,74 & --- & --- & 20,94 & 6,74 & --- & --- \\
\hline LN_INN_SER & --- & --- & 20,36 & 3,09 & --- & --- & 20,26 & 3,81 \\
\hline SC_RND & 2449 & 5259 & 4790 & 16944 & 3721 & 7612 & 4341 & 17490 \\
\hline SC_DESIG & 159 & 369 & 48 & 279 & 108 & 308 & 52 & 224 \\
\hline FC_EQU & 6012 & 13730 & 498 & 1261 & 4377 & 8877 & 1335 & 3270 \\
\hline SC_TECH & 145 & 406 & 24 & 159 & 83 & 198 & 84 & 368 \\
\hline SC_PAT & 59 & 233 & 1 & 4 & 37 & 136 & 16 & 62 \\
\hline SC_SOFT & 165 & 442 & 176 & 1176 & 187 & 428 & 250 & 1542 \\
\hline SC_INGI & 1351 & 3411 & 289 & 1293 & 1303 & 4254 & 598 & 2246 \\
\hline HC_EDU & 19 & 72 & 5 & 20 & 15 & 54 & 8 & 27 \\
\hline RC_MARK & 6 & 19 & 52 & 466 & 7 & 28 & 7 & 30 \\
\hline FC_OTHER & 948 & 3233 & 499 & 2179 & 1031 & 3324 & 585 & 3057 \\
\hline
\end{tabular}

The results of the analysis of regression coefficients in the third type models show that investments in intellectual capital have a significant and positive effect on the innovative performance of companies in 2017 and 2018 (Table 4). Investments in digital intellectual capital have a positive impact on innovative performance only in 2018, and structural capital is critical for all companies. Investments in software impact positively on a significant part of the revenue growth from innovative products and services. In addition, service-oriented companies make more use of human and relational capital. In 2017, investments in human capital showed positive results and significantly increased the innovative performance of service-oriented companies. Thus, we have confirmed the second hypothesis of the study. On the one hand, investments in structural digital capital play a significant positive role in increasing the innovative performance of companies, expressed in an additional stream of revenue from the sale of innovative goods and services. On the other hand, service companies rely on human and relational capital to create value, investing in employee training and market research. During this time, manufacturing companies make heavy use of structural capital, investing resources in research and development, as well as purchasing software.

Table 4. Unstandardized regression coefficients for testing the second hypothesis.

\begin{tabular}{|c|c|c|c|c|c|c|}
\hline \multirow[b]{3}{*}{ Variables } & \multicolumn{6}{|c|}{ Model 3. Dependent: sales of innovation goods and services, 2017} \\
\hline & \multicolumn{2}{|c|}{ Manufacturing } & \multicolumn{2}{|c|}{ Service } & \multicolumn{2}{|c|}{ All companies } \\
\hline & $\mathrm{b}$ & $\mathrm{t}$ & $\mathrm{b}$ & $\mathrm{t}$ & $\mathrm{b}$ & $\mathrm{t}$ \\
\hline Constant & 0,446 & 0,47 & $11,8^{* * *}$ & 11,88 & $10,1 * * *$ & 5,97 \\
\hline SC_RND & $0,178 * * *$ & 2,82 & 0,071 & 1,93 & 0,057 & 1,48 \\
\hline SC_DESIG & 0,033 & 0,74 & 0,016 & 0,42 & 0,027 & 1,11 \\
\hline FC_EQU & $0,798 * * *$ & 10,87 & $0,344 * * *$ & 4,83 & $0,464 * * *$ & 4,26 \\
\hline SC_TECH & 0,026 & 0,48 & 0,011 & 0,19 & 0,044 & 1,47 \\
\hline SC_PAT & $-0,012$ & $-0,23$ & 0,051 & 0,80 & 0,007 & 0,24 \\
\hline SC_SOFT & 0,058 & 0,91 & $-0,058$ & $-1,39$ & 0,010 & 0,22 \\
\hline SC_INGI & $-0,010$ & $-0,16$ & $-0,005$ & $-0,16$ & $-0,003$ & $-0,09$ \\
\hline HC_EDU & 0,040 & 0,56 & $0,109^{* *}$ & 2,19 & 0,063 & 1,33 \\
\hline
\end{tabular}


Table 4. Continued

\begin{tabular}{|c|c|c|c|c|c|c|}
\hline RC_MARK & $-0,072$ & $-1,37$ & 0,033 & 0,74 & 0,033 & 1,14 \\
\hline FC_OTHER & 0,063 & 1,28 & 0,053 & 1,63 & $-0,007$ & $-0,22$ \\
\hline $\mathrm{R}^{2}$ & \multicolumn{2}{|c|}{0,884} & \multicolumn{2}{|c|}{0,665} & \multicolumn{2}{|c|}{0,781} \\
\hline Adj. $R^{2}$ & \multicolumn{2}{|c|}{0,868} & \multicolumn{2}{|c|}{0,619} & \multicolumn{2}{|c|}{0,752} \\
\hline $\mathrm{F}$ & \multicolumn{2}{|c|}{$56,3 * * *$} & \multicolumn{2}{|c|}{$14,7^{* * *}$} & \multicolumn{2}{|c|}{$26,4 * * *$} \\
\hline Durbin-Watson & \multicolumn{2}{|c|}{1,729} & \multicolumn{2}{|c|}{1,763} & \multicolumn{2}{|c|}{2,138} \\
\hline $\mathrm{N}$ (regions) & \multicolumn{2}{|c|}{85} & \multicolumn{2}{|c|}{85} & \multicolumn{2}{|c|}{85} \\
\hline \multirow[b]{3}{*}{ Variables } & \multicolumn{6}{|c|}{ Model 3. Dependent: sales of innovation goods and services, 2018} \\
\hline & \multicolumn{2}{|c|}{ Manufacturing } & \multicolumn{2}{|c|}{ Service } & \multicolumn{2}{|c|}{ All companies } \\
\hline & $\mathrm{b}$ & $\mathrm{t}$ & $\mathrm{b}$ & $\mathrm{t}$ & $\mathrm{b}$ & $\mathrm{t}$ \\
\hline Constant & $-0,213$ & $-0,16$ & $12,7 * * *$ & 8,96 & $10,2 * * *$ & 9,75 \\
\hline SC_RND & 0,034 & 0,30 & $-0,006$ & $-0,07$ & 0,026 & 0,52 \\
\hline SC_DESIG & 0,000 & 0,00 & $-0,096$ & $-1,64$ & $-0,085 * *$ & $-2,62$ \\
\hline FC_EQU & $0,75^{* * * *}$ & 5,10 & $0,254 * *$ & 2,12 & $0,51 * * *$ & 6,66 \\
\hline SC_TECH & 0,000 & 0,00 & 0,093 & 1,42 & 0,046 & 1,28 \\
\hline SC_PAT & 0,063 & 0,99 & 0,002 & 0,03 & 0,040 & 1,19 \\
\hline SC_SOFT & $0,337 * * *$ & 3,16 & $0,299 * * *$ & 3,17 & $0,146^{* * *}$ & 2,97 \\
\hline SC_INGI & $-0,153$ & $-1,61$ & $0,24 * * *$ & 2,93 & 0,052 & 1,12 \\
\hline HC_EDU & 0,101 & 1,08 & 0,096 & 1,11 & $0,131 * * *$ & 2,72 \\
\hline RC_MARK & $-0,054$ & $-0,81$ & $0,122 *$ & 1,81 & 0,033 & 0,94 \\
\hline FC_OTHER & $0,142 * *$ & 2,35 & $0,111^{*}$ & 1,88 & 0,078 & 2,50 \\
\hline $\mathrm{R}^{2}$ & \multicolumn{2}{|c|}{0,832} & \multicolumn{2}{|c|}{0,610} & \multicolumn{2}{|c|}{0,814} \\
\hline Adj. $R^{2}$ & \multicolumn{2}{|c|}{0,810} & \multicolumn{2}{|c|}{0,558} & \multicolumn{2}{|c|}{0,788} \\
\hline $\mathrm{F}$ & \multicolumn{2}{|c|}{$36,7 * * *$} & \multicolumn{2}{|c|}{$11,5^{* * *}$} & \multicolumn{2}{|c|}{$32,3 * * *$} \\
\hline Durbin-Watson & \multicolumn{2}{|c|}{1,875} & \multicolumn{2}{|c|}{1,771} & \multicolumn{2}{|c|}{1,812} \\
\hline $\mathrm{N}$ (regions) & \multicolumn{2}{|c|}{85} & 8 & & 85 & \\
\hline
\end{tabular}

Note. $*$ significant at $<10 \%$; ** significant at $<5 \%$; *** significant at $<1 \%$.

As expected at the stage of developing hypotheses, control variables reflecting investments in elements of physical capital play a positive role in shaping the innovative performance of manufacturing and service-oriented companies. Though digitalization in Russian regions reflects the formation of additional flows of specific intellectual capital, it remains at the initial stage of maturity. Regions are characterized by heterogeneity in the adaptation of digital technologies, and a significant part of the return on investment falls on the elements of digital structural capital, retaining the logic of manufacturing productoriented companies of the industrial era.

\section{Conclusions}

Digitalization plays a significant role in determining the competitive advantages of companies in local, regional and Int. markets in modern conditions. In this study, using the example of Russian companies, the positive contribution of digitalization to the economic development of regions is shown, since new information technologies cause an increase in the gross regional product and revenues of companies. This paper closes a gap in the literature as most previous research either look at individual experience of companies or touch upon general indicators of digitalization, neglecting its impact on innovations at regional level. This work complements the theory of intangible resources, highlighting digital intellectual capital specific to modern companies. 
The results of the study showed that digitalization has a positive, significant, but relatively moderate contribution to improving the financial performance of Russian companies. Therefore, we have confirmed the first hypothesis. At the current stage of digital maturity, the main component of intangible resources is structural capital - codified knowledge that forms the basis of technological solutions and software development, for example, ERP systems, cloud services and radio frequency identifiers. The estimates obtained indicate only a moderate contribution of digitalization to economic development, because of the heterogeneity in the regional digital infrastructure development. In such conditions, Russia continues to be a developing digital economy, but companies in a number of regions have significant digital potential. In addition, we confirmed the second hypothesis: investments in digital intellectual capital components have a positive impact on the innovative performance of companies. At the same time, companies in the manufacturing sector obtain a positive return on investment in structural capital, while service-oriented companies intensively use relational and human capital. The results obtained can be used in practice in the business community and in the field of regional economic regulation when developing investment strategies. The results can also be applied in practice when searching for priority areas of investment in elements of intellectual capital.

A limitation of the study is the regional approach, in which companies are viewed in a single ecosystem that generates overall performance. This assumes that we summarize the results of companies' work in the field of digitalization, reflecting only the total contribution of intellectual capital to economic development. In further research, it is necessary to focus on studying the contribution of digitalization at the level of individual companies and to trace through examples the mechanisms of the influence of intellectual capital on the performance and added value in local companies.

\section{References}

1. J. Švarc, J. Lažnjak, M. Dabić, J. of Intellectual Capital (2020)

2. G. Secundo, M. Massaro, J. Dumay, C. Bagnoli, J. of Intellectual Capital, 19 (2018)

3. M. Kotarba, Foundations of Management, 9 (2017)

4. E. Hofmann, H. Sternberg, H. Chen, A. Pflaum, G. Prockl, Int. J. of Physical Distribution \& Logistics Management, 49 (2019)

5. S. Saengchai, K. Jermsittiparsert, Int. J. of Supply Chain Management, 8 (2019)

6. T. Umans, M. Kockum, E. Nilsson, S. Lindberg, Int. J. of Workplace Health Management, 11 (2018)

7. A. Neligan, Intereconomics, 53 (2018)

8. S. Rajput, S.P. Singh, Benchmarking: An Int. J., 1 (2019)

9. J.M. Müller, J. of Manufacturing Technology Management, 30 (2019)

10. M. Rachinger, R. Rauter, C. Müller, W. Vorraber, E. Schirgi, J. of Manufacturing Technology Management, 30 (2019)

11. Cijan, L. Jenič, A. Lamovšek, J. Stemberger, Dynamic Relationships Management J., 8 (2019)

12. M. Wilkesmann, U. Wilkesmann, VINE J. of Information and Knowledge Management Systems, 48 (2018)

13. L. Viale, D. Zouari, Supply Chain Forum: An Int. J., (2020)

14. M. Ghobakhloo, J. of Manufacturing Technology Management, 29 (2018) 
15. O.A. Romanova, E.A. Kuzmin, WSEAS Transactions on business and economics, $\mathbf{1 7}$ (2020)

16. D. Ibarra, J. Ganzarain, J.I. Igartua, Procedia Manufacturing, 22 (2018)

17. M. Kosacka-Olejnik, R. Pitakaso, Logforum, 15 (2019)

18. Y. Turovets, K. Vishnevskiy, Engineering Management in Production and Services, 11 (2019)

19. S. Vasin, L. Gamidullaeva, E. Shkarupeta, I. Palatkin, T. Vasina, European Research Studies J., XXI (2018)

20. V.N. Ivanova, A.L. Poltarykhin, A. Szromnik, O. Anichkina, Entrepreneurship and Sustainability Issues, 7 (2019)

21. E. Brynjolfsson, S. Yang, Advances in Computers, 43 (1996)

22. C.C. Liu, Int. J. of Electronic Finance, 2 (2008)

23. M. Molodchik, S. Paklina, P. Parshakov, Meditari Accountancy Research, 26 (2018)

24. Marr, K. Moustaghfir, Management Decision, 43 (2005)

25. G. Roos, S. Pike, L. Fernstrom, Managing Intellectual Capital in Practice (2007)

26. Aghimien, C. Aigbavboa, A. Oke, W. Thwala, P. Moripe, Int. J. of Construction Management, 1 (2020)

27. J. Wonglimpiyarat, J. of High Technology Management Research, 30 (2019)

28. A. Zangiacomi, E. Pessot, R. Fornasiero, M. Bertetti, M. Sacco, Production Planning and Control, 31 (2020)

29. N. Bontis, J. of Intellectual Capital, 5 (2004)

30. M. Molodchik, E. Shakina, A. Bykova, J. of Intellectual Capital, 13 (2012)

31. O.V. Glinkina, S.A. Ganina, A.V. Maslennikova, T.A. Solostina, M. ViktorovnaSoloveva, Int. J. of Management, 11 (2020)

32. T.J.A. Peng, J.C.H. Yang, S. Pike, G. Roos, Int. J. of Learning and Intellectual Capital, 8 (2011)

33. A.M. Subramanian, V. van de Vrande, J. of Operations Management, 65 (2019)

34. J. Rooney, J. Dumay, The British Accounting Review, 48 (2016)

35. K. Phusavat, N. Comepa, A. Sitko-Lutek, K. Ooi, Industrial Management \& Data Systems, 111 (2011)

36. Q.L. Kweh, Y.C. Chan, I.W.K. Ting, J. of Intellectual Capital, 14 (2013)

37. P.S. Kasoga, Cogent Economics \& Finance, 8 (2020)

38. T. Andreeva, T. Garanina, J. of Intellectual Capital, 17 (2016)

39. M.D.R. Cabrita, N. Bontis, Int. J. of Technology Management, 43 (2008)

40. B. Cuozzo, J. Dumay, M. Palmaccio, R. Lombardi, J. of Intellectual Capital, 18 (2017)

41. K.H. Leitner, Int. J. of Technology Management, 53 (2011)

42. C.M. Jardon, Knowledge Management Research \& Practice, 13 (2015)

43. T. Andreeva, A. Kianto, J. of Knowledge Management, 15 (2011)

44. A. Kianto, P. Ritala, J.-C. Spender, M. Vanhala, J. of Intellectual Capital, 15 (2014)

45. S.M. Okladnikov, N.S. Boulgakova, L.M. Gokhberg, Regions of Russia: Social and Economic Indicators (2019)

46. L.M. Gokhberg, K.A. Ditkovsky, E.I. Evnevich, S. V. Kuznetsova, I. A. Martynova, T.V. Ratay, L.A. Rosovetskaya, Indicators of Innovation in the Russian Federation 
(2020)

47. L. Gokhberg, K. Ditkovskiy, I. Kuznetsova, E. Lukinova, S. Martynova, T. Ratay, L. Rosovetskaya, S. Fridlyanova, Indicators of Innovation in the Russian Federation (2019)

48. G. Abdrakhmanova, K. Vishnevskiy, L. Gokhberg, Digital Economy Indicators in the Russian Federation (2020) 